\title{
$\mathrm{ABO}$ 혈청형 검사시약인 DiaCell $\mathrm{ABO}$ 적혈구 시약의 평가
}

임영애

아주대학교 의과대학 진단검사의학교실

\section{Evaluation of DiaCell ABO Red Blood Cell Reagents as a Reverse Typing for ABO Blood Group}

\author{
Young Ae Lim \\ Department of Laboratory Medicine, Ajou University School of Medicine, Suwon, Korea
}

Background: Because ABO reverse typing reagents approved by the Ministry of Food and Drug Safety (MFDS) for manual typing are rare in Korea, 3\% DiaCell $\mathrm{ABO} \mathrm{A}_{1}$ red blood cell (RBC) reagents (DiaCell $\mathrm{A}_{1}, \mathrm{BioRad}$, DiaMed, Cressier, Switzerland) and DiaCell ABO B RBC reagents (DiaCell B) for a manual technique were compared with already approved $\mathrm{RBC}$ reagents for the acquisition of an import permit.

Methods: Residual plasmas or sera were collected after routine ABO grouping or other tests. The reverse typing tests were performed by a manual tube technique with DiaCell $\mathrm{A}_{1} \& \mathrm{~B}$ as the test reagents and 0.8\% ID-DiaCell $\mathrm{ABO} \mathrm{A}_{1} \& \mathrm{~B} \mathrm{RBC}$ reagents, ID-Card for $\mathrm{NaCl}$, and an $\mathrm{IH}-1000$ autoanalyzer from the same manufacturer of DiaCell $\mathrm{A}_{1} \& \mathrm{~B}$ as the control reagents. Agreements, clinical sensitivities and clinical specificities between test and control reagents were calculated.

Results: Comparison tests were performed in 1000 samples, and agreements were $99.9 \%$ for DiaCell $\mathrm{A}_{1}$ and $100.0 \%$ for DiaCell B. Clinical sensitivities and clinical specificities were $99.9 \%$ and $100.0 \%$ for DiaCell $A_{1}$ and all $100.0 \%$ for DiaCell B, respectively.

Conclusion: Because the evaluation results of DiaCell $\mathrm{A}_{1}$ and $\mathrm{B}$ were all satisfied with more than $99 \%$ as the evaluation criteria of MFDS, they were concluded to be suitable for use as ABO reverse typing reagents for manual typing. The results of this study are also expected to be useful in the design of clinical trials for approval of future in vitro medical devices. (Korean J Blood Transfus 2017;28:58-66)

Key words: ABO blood group, Reverse typing, In vitro medical device 


\section{서 론}

$\mathrm{ABO}$ 혈액형은 면역원성이 가장 강한 매우 중 요한 혈액형으로 $\mathrm{ABO}$ 혈액형 검사는 급성면역 용혈수혈부작용을 방지하기 위하여 수혈시의 환 자와 헌혈자, 초급성 거부반응을 방지하기 위하 여 장기이식시의 수혜자와 공여자, 그리고 신생 아태아용혈질환을 진단하기 위하여 산모와 신생 아에서 실시하며, 친자감별의 목적으로도 사용되 는 중요한 검사이다.

$\mathrm{ABO}$ 혈액형 검사는 항-A 시약과 항-B 시약을 이용하여 환자의 혈구 항원을 검사하는 혈구형 검사와 혈액형을 알고 있는 $\mathrm{A}$ 혈구와 $\mathrm{B}$ 혈구를 환자의 혈청이나 혈장과 반응하여 항-A 항체와 항-B 항체의 존재 유무에 따라 판정하는 혈청형 검사 두 가지를 모두 시행하여 일치하는 경우에 만 $\mathrm{ABO}$ 혈액형 판정을 실시하여야 한다. 혈액형 검사 기법으로는 시험관법과 슬라이드법을 이용 하는 수기법과 원주응집법 등을 포함한 다양한 기법의 자동화 방법들이 있다. 수기법을 사용할 경우에는 검사자가 검체에 직접 노출될 위험과 슬라이드가 건조하면서 발생할 위양성 위험 때문 에 슬라이드법보다 시험관법을 권장한다. 또한 혈청형 검사의 경우에는 혈청에 포함된 항체가가 높지 않으므로 민감도가 더 높은 시험관법을 권 장한다. ${ }^{1)}$

$\mathrm{ABO}$ 혈청형 검사에 이용되는 혈구의 농도는 검사기법에 따라 다른데 시험관법은 $2 \sim 5 \%$, 슬 라이드법은 30 50\%가 사용되며, ${ }^{2)}$ 자동화 장비 는 제조사에 따라 다르기는 하나 원주응집법인 경우 $0.8 \%$ 농도가 사용된다. 비록 원주응집법을 포함한 자동화 장비의 사용이 증가하고 있는 추 세이기는 하나, 아직도 $90 \%$ 이상의 검사실에서 는 슬라이드법이나 시험관법의 수기법을 더 많이 이용하고 있는 실정이다. ${ }^{3}$ 수기법에는 검사실에
서 제조한 적혈구 시약을 많이 이용하고 있으나, 자가제조 관리 및 정도관리 등의 이유로 상품화 적혈구 시약을 사용하는 검사실들이 최근 증가하 여 2015년에 약 38\% 정도로 보고되었다. ${ }^{3)}$ 그러나 국내에는 식품의약품안전처로부터 체외진단기 기로 허가 받은 수기용 혈청형 검사 적혈구 시약 은 드문 실정이다.

이에 본 연구에서는 수기법 검사용으로 제조된 DiaCell $\mathrm{ABO} \mathrm{A}_{1}$ 적혈구 시약과(Biorad, DiaMed, Cressier, Switzerland)와 DiaCell ABO B (Biorad) 적혈구 시약을 동일 제조사의 성능이 입증된 기 허가 체외진단기기 중 자동화 원주응집법의 원리 로 혈액형을 검사하는 시약과 비교하는 확증 임 상시험을 통하여 식품의약품안전처의 체외진단 용 의료기기 수입품목허가를 받고자 하였고, 이 를 보고하여 향후 유사한 임상시험의 연구 설계 시 도움을 주고자 하였다.

\section{대상 및 방법}

이 연구는 아주대학교병원의 기관생명윤리심 의위원회의 승인을(AJIRB0DEV0DE1-15-092) 득 한 후 임상시험을 실시하였다.

\section{1. 검체 수집}

식품의약품안전처에서 발간한 최신 개정된 $\mathrm{ABO}$ 혈액형[혈구형/혈청형] 검사용 시약의 허가 심사 가이드라인(이하 가이드라인으로 약함)에 ${ }^{4)}$ 의하면 3000 검체를 사용하여 평가를 시행하여야 한다. 그러나 시험용 시약인 수기법 검사용 $3 \%$ $( \pm 1 \%)$ DiaCell $\mathrm{ABO} \mathrm{A}_{1}$ 과 DiaCell $\mathrm{ABO}$ B는 기 허 가된 제품(수허13-2190호, $\mathrm{ABO} . \mathrm{RhD}$ 혈액형검사시 약)인 $0.8 \%$ ( $\pm 0.1 \%)$ ID-DiaCell $\mathrm{ABO} \mathrm{A}_{1}$ 과(Biorad, DiaMed, Cressier, Switzerland) ID-DiaCell ABO B (Biorad) 적혈구시약과 동일한 제형으로 희석 등 
의 변형제품이므로 1,000 검체만 사용해 평가하 여도 가능하다는 식품의약품안전처의 승인에 따 라 탈락율 $10 \%$ 포함하여 총 1,100 검체를 가이드 라인의 검체 선정기준에 따라 최소 검체 기준이 포함되도록 수집하였다(Tables 1, 2).

검체는 본 임상시험과 무관하게 2016년 7월부 터 10 월까지 통상적인 $\mathrm{ABO}$ 혈액형 검사가 의뢰 된 환자의 검사 후 잔여 혈장 혹은 기타 검사 후 혈청 검체를 수집하여 본 연구에 사용 전까지 냉 동 조건으로 보관하였다. 단, 검체 조건이 '채혈 후 3 일 이내의 신선한 검체’일 경우는 냉동이 아
니라 채혈 후 3 일 이내의 검체로 한정하여 수집 하였고, 혈액형 변이형 영향 확인을 위한 검체는 대한적십자사 혈액원으로부터 구입한 해당 잔여 검체를 이용하였다. 검체는 가이드라인에 준하여 선정하되, 혈청이나 혈장의 검체량이 $500 \mu \mathrm{L}$ 이 하이거나 검체가 응고되어 수기 시험관법으로 $\mathrm{ABO}$ 혈청형 검사를 모두 수행하기 곤란한 경우 그리고 적혈구 응집 판정에 영향을 줄 수 있는 용 혈 검체와 혼탁한 검체는 제외하였다. 단, 가이드 라인에 따라 선정된 간섭물질의 영향 확인을 위 한 고지혈 검체 및 용혈된 검체는 제외기준을 적

Table 1. Number of samples and results of evaluation of DiaCell $A_{1}$

\begin{tabular}{|c|c|c|c|c|c|}
\hline Samples with & $\begin{array}{l}\text { Minimum } \\
\text { number* }\end{array}$ & $\begin{array}{c}\text { Samples } \\
\text { tested }\end{array}$ & $\begin{array}{c}\text { Samples } \\
\text { excluded }^{\dagger}\end{array}$ & $\begin{array}{c}\text { Samples } \\
\text { analyzed }\end{array}$ & Agreement $^{\ddagger} \%$ \\
\hline Patients & 100 & 303 & 6 & 297 & 99.7 \\
\hline Blood group A & 300 & 315 & 15 & 300 & 100.0 \\
\hline Blood group B & 300 & 314 & 13 & 301 & 99.7 \\
\hline Clotted samples & 10 & 10 & 0 & 10 & 100.0 \\
\hline Anti-coagulation (EDTA, CPDA etc.) & 10 & 11 & 1 & 10 & 100.0 \\
\hline Fresh samples within three days from collection & 10 & 52 & 0 & 52 & 100.0 \\
\hline$\geq 80$ year old age & 10 & 11 & 0 & 11 & 100.0 \\
\hline $\mathrm{ABO}$ subgroups & 6 & 7 & 1 & 6 & 100.0 \\
\hline Diseases with abnormal serum proteins & 10 & 11 & 0 & 11 & 90.9 \\
\hline Pregnant women & 5 & 7 & 0 & 7 & 100.0 \\
\hline Positive direct anti-globulin test & 5 & 5 & 0 & 5 & 100.0 \\
\hline Lipemia & 5 & 5 & 0 & 5 & 100.0 \\
\hline Hemolysis & 5 & 5 & 0 & 5 & 100.0 \\
\hline Total & 1000 & 1031 & 31 & 1000 & 99.9 \\
\hline \multirow{2}{*}{ Diacell $\mathrm{A}_{1}$} & \multicolumn{3}{|c|}{ Approved reagents } & \multirow{2}{*}{ Sensitivity $^{\ddagger}$} & \multirow{2}{*}{ Specificity $^{\ddagger}$} \\
\hline & Positive & Negative & Total & & \\
\hline Positive & 569 & 0 & 569 & $99.8 \%$ & $100.0 \%$ \\
\hline Negative & 1 & 430 & 431 & & \\
\hline Total & 570 & 430 & 1000 & & \\
\hline
\end{tabular}

*Minimum required sample number according to Ministry of Food and Drug Safety; ${ }^{\dagger}$ Number of samples excluded based on exclusion criteria in the study; ${ }^{\ddagger}$ Agreement, sensitivity and specificity between tube manual techniques using Diacell $\mathrm{A}_{1}$ and gel column agglutination test using approved reagents by $\mathrm{IH}-1000$. 
Table 2. Number of samples and results of evaluation of DiaCell $\mathrm{B}$

\begin{tabular}{|c|c|c|c|c|c|}
\hline Samples with & $\begin{array}{l}\text { Minimum } \\
\text { number* }\end{array}$ & $\begin{array}{c}\text { Samples } \\
\text { tested }\end{array}$ & $\begin{array}{c}\text { Samples } \\
\text { excluded }^{\dagger}\end{array}$ & $\begin{array}{l}\text { Samples } \\
\text { analyzed }\end{array}$ & Agreement ${ }^{\dagger} \%$ \\
\hline Patients & 100 & 303 & 6 & 297 & 100.0 \\
\hline Blood group A & 300 & 315 & 15 & 300 & 100.0 \\
\hline Blood group B & 300 & 314 & 13 & 301 & 100.0 \\
\hline Clotted samples & 10 & 10 & 0 & 10 & 100.0 \\
\hline Anti-coagulation (EDTA, CPDA etc.) & 10 & 11 & 1 & 10 & 100.0 \\
\hline Fresh samples within three days from collection & 10 & 52 & 0 & 52 & 100.0 \\
\hline$\geq 80$ year old age & 10 & 11 & 0 & 11 & 100.0 \\
\hline $\mathrm{ABO}$ subgroups & 6 & 7 & 1 & 6 & 100.0 \\
\hline Diseases with abnormal serum proteins & 10 & 11 & 0 & 11 & 100.0 \\
\hline Pregnant women & 5 & 7 & 0 & 7 & 100.0 \\
\hline Positive direct anti-globulin test & 5 & 5 & 0 & 5 & 100.0 \\
\hline Lipemia & 5 & 5 & 0 & 5 & 100.0 \\
\hline Hemolysis & 5 & 5 & 0 & 5 & 100.0 \\
\hline Total & 1000 & 1031 & 31 & 1000 & 100.0 \\
\hline \multirow{2}{*}{ Diacell B } & \multicolumn{3}{|c|}{ Approved reagents } & \multirow{2}{*}{ Sensitivity $^{\dagger}$} & \multirow{2}{*}{ Specificity $^{\ddagger}$} \\
\hline & Positive & Negative & Total & & \\
\hline Positive & 569 & 0 & 569 & $100.0 \%$ & $100.0 \%$ \\
\hline Negative & 0 & 431 & 431 & & \\
\hline Total & 569 & 431 & 1000 & & \\
\hline
\end{tabular}

*Minimum required sample number according to Ministry of Food and Drug Safety; ${ }^{\dagger}$ Number of samples excluded based on exclusion criteria in the study; ${ }^{\ddagger}$ Agreement, sensitivity and specificity between tube manual techniques using Diacell $\mathrm{B}$ and gel column agglutination test using approved reagents by $\mathrm{IH}-1000$.

용하지 않았다.

\section{2. 검사방법}

보관된 검체를 이용하여 검사는 2016년 9월부 터 10 월 사이에 시행하였다. 시험 검사법은 임상 시험용 체외진단기기인 적혈구시약인 DiaCell $\mathrm{ABO} \mathrm{A}_{1}$ 과 DiaCell $\mathrm{ABO} B$ cell를 사용하여 시험 관법으로 제조사의 설명서에 준하여 $\mathrm{ABO}$ 혈청 형 검사를 시행하였다. 혈구응집을 음성인 '-’로 부터 '4+'까지 판정하였고," 용혈 및 혼합시야가 있을 경우 판정하되, $1+$ 이상의 응집을 보이거
나 용혈을 보이는 경우를 양성으로 판정하고, 응 집이 없는 경우를 음성으로 간주하고, 이 이외에 는 판정불가로 판정하였다. 검사자와 판독자는 모두 4명으로 임상시험 전 미리 검사와 시험관법 혈구 응집 판독에 관한 충분한 교육을 실시하여 판독자에 따른 응집 강도 차이를 배제하였다.

대조군 시약으로는 기허가된 ID-DiaCell ABO $\mathrm{A}_{1}$ 과 ID-DiaCell $\mathrm{ABO} \mathrm{B}$ 적혈구 시약, $\mathrm{NaCl}$, Enzyme Test and Cold Agglutinins용 ID-Card (Biorad, DiaMed, Cressier, Switzerland), 그리고 IH-1000 (Biorad, DiaMed, Cressier FR, Switzerland) 자동혈액형판정 
장치를 이용하여 제조사의 설명서대로 $\mathrm{ABO}$ 혈 청형 검사를 시행하였고, 제조사 기준에 의하여 장비가 판정한 '-’로 부터 '4+'까지의 혈구응집 결과를 응집 강도로 간주하였다.

\section{3. 연구설계}

아주대학교병원 일상검사에 의뢰되어 검사 후 남은 잔여검체 중 본 연구에 필요한 검체를 분류 하고 해당 임상기관의 검체관리담당자에 의하여 식별화 과정을 거쳐 모든 검체에 식별화 코드를 부여하여 검사자들이 환자 인적사항을 확인하지 못하게 하였다. 식별화가 완료된 검체는 $\mathrm{ABO}$ 혈 청형 검사를 진행하였고, 검체관리담당자는 식별 화 이전의 혈구형과 혈청형 검사가 시행된 기검 사 결과도 시험군과 대조군의 결과가 불일치할 경우의 원인 규명을 위하여 보관하였다. 기검사 는 대조군과 동일한 검사법인 겔 원주응집법을 이용한 $\mathrm{IH}-1000$ 자동화기기로 $\mathrm{A}_{1}$ 적혈구를 이용 하였다. 임상시험용 체외진단기기의 결과 판정 항목에 따라 결과를 판정하고 그 결과를 검사를 진행하는 곳에서 바로 검사결과지에 수기로 옮겨 적은 후 이를 다시 증례기록서에 작성하였다. 이 검체들은 대조검사법인 $\mathrm{IH}-1000$ 을 사용하여 자 동화 원주응집법의 원리로 $\mathrm{ABO}$ 혈액형 혈청형 검사를 통해 응집소 여부를 판정하였다. 판정 시 $\mathrm{A}_{1}$ 과 $\mathrm{B}$ 적혈구의 응집은 각각 항-A 및 항-B 응집 소가 존재한다는 것을 나타내고 응집이 없으면 응집소가 존재하지 않음을 나타내었는데, 응집소 존재 유무 이외에도 혈구응집 강도도 비교하였 다.

시험군의 최종 판정된 결과를 기반으로 1 차적 으로 대조군과의 일치도를 분석하고 2차적으로 임상적 민감도와 특이도를 분석하였는데 시험군 DiaCell $\mathrm{ABO} \mathrm{A}_{1}$ 과 DiaCell $\mathrm{ABO} B$ 각각에 대하여 산정하였다. 일치도의 기준은 식품의약품안전처
에서 제시한 시험시약과 대조시약의 일치도인 $\mathrm{A}_{1}$ 적혈구 응집 $99 \%$ 이상, $\mathrm{B}$ 적혈구 응집 $99 \%$ 이상으로 하였다. 시험군과 대조군의 결과가 불 일치하는 경우 검체관리담당자가 관리하는 기검 사 결과와 비교하여 시험군이 일치할 경우에는 냉동검체 오염으로 판정하여 통계에서 탈락시키 고, 기검사 결과가 대조군과 일치할 경우에는 시 험군을 불일치로 판정하였다. 또한 시험 도중 시 험법을 의도하지 않게 지키지 못하거나 예측하지 못한 사고로 인해 시험이 잘못된 결과가 나온 경 우와 추가로 검사할 검체량이 부족 할 경우에는 검체를 '탈락'하는 것으로 하였고, 만약 탈락사유 로 검체 수 산정기준에 미달될 경우에는 승인된 검체 수 범위 내에서 해당 수 만큼 잔여 검체를 추가하였다. 민감도는 $\mathrm{ABO}$ 혈청형 혈액형 검사 에서 검체 내 존재하는 항-A와 항-B 동종 응집소 유무에 따라 시험군과 반응하는 비율이며, 임상 적 특이도는 동종 응집소 유무에 따라 시험군과 반응하지 않은 비율로 정의하였다.

응집 정도가 불일치하는 경우 DiaCell $\mathrm{A}_{1}$ 과 DiaCell B 적혈구들이 두 가지 방법 중 어느 방법 에서 더 강한 응집을 보이는지 여부를 검증하기 위하여 Chi-square test를 실시하였으며, $P<0.05$ 를 유의한 것으로 간주하였다.

\section{결 과}

본 임상시험에 등록된 최종 검체 수는 1031개 인데 이중 냉동검체 오염으로 판정된 28개와 검 체 안정성 문제로 판정된 3 개의 31 개의 검체가 중도탈락되었다. 이중 '검체 안정성 문제'로 판정 된 3 개 검체의 경우, 시험군 및 대조군의 검사결 과는 서로 일치하나 이 결과가 기 검사 결과가 불 일치하여 예측하지 못한 사고로 인하여 검체가 바뀐 된 것으로 간주하여 중도탈락 처리하였다. 


\section{1. 일치도}

임상시험용 체외진단기기인 DiaCell $\mathrm{A}_{1}$ 적혈구 는 탈락 검체를 제외한 1000 개 검체 중 999 개의 검체에서 항-A 응집소를 검출하여 기허가 제품 인 대조시약과 $99.9 \%$ 에서 일치된 결과를 보였다 (Table 1). 불일치를 보인 1 개의 검체는 기허가 제 품인 대조시약에서는 $1+$ 응집정도로 항-A 응집 소를 검출한 반면 $\mathrm{DiaCell} \mathrm{A}_{1}$ 는 환자 검체내 항-A 응집소를 검출하지 못하였던 경우였다. DiaCell B 적혈구는 탈락검체를 제외한 1000 개 검체 모두에 서 항-B 응집소를 검출하여 대조시약과 $100.0 \%$ 일치된 결과를 보였다(Table 2).

\section{2. 민감도와 특이도}

임상시험용 체외진단기기인 $\mathrm{DiaCell} \mathrm{A}_{1}$ 적혈구 는 대조시약에서 항-A 응집소가 검출되었던 570 검체 중 1 개를 제외한 569 검체에서 항-A 응집소 를 검출하여 $99.9 \%$ 의 민감도를 보였다. 또한 대 조군에서 항-A 응집소가 검출되지 않았던 430 검체 모두에서 항-A 응집소를 검출하지 않아 $100.0 \%$ 의 특이도를 보였다(Table 1).

Table 3. Number of samples according to the grade of hemagglutination for $\mathrm{ABO}$ serum typing using DiaCell $A_{1}$ between tube and gel column agglutination tests

\begin{tabular}{lcccccc}
\hline \multirow{2}{*}{ Tube } & \multicolumn{6}{c}{ Gel column } \\
\cline { 2 - 7 } & Neg & $1+$ & $2+$ & $3+$ & $4+$ & All \\
\hline Neg & 430 & 1 & 0 & 0 & 0 & 431 \\
$1+$ & 0 & 1 & 1 & 1 & 0 & 3 \\
$2+$ & 0 & 0 & 12 & 8 & 11 & 31 \\
$3+$ & 0 & 0 & 19 & 47 & 64 & 130 \\
$4+$ & 0 & 0 & 14 & 39 & 352 & 405 \\
All & 430 & 2 & 46 & 95 & 427 & 1000
\end{tabular}

임상시험용 체외진단기기인 DiaCell B 적혈구 는 기허가 제품인 대조시약에서 항-B 응집소를 검출하였던 569 검체 모두에서 항-B 응집소를 검 출하여 $100.0 \%$ 의 민감도를 보였다. 또한 대조시 약에서 항-B 응집소가 검출되지 않았던 431검체 모두에서 항-B 응집소를 검출하지 않아 $100.0 \%$ 의 특이도를 보였다(Table 2).

\section{3. 두 방법간의 혈구 응집강도 비교}

본 연구에서 시험시약인 수기 시험관법과 겔 원 주응집법을 사용하여 $\mathrm{IH}-1000$ 자동화기기를 이용 한 대조시약의 혈구응집을 비교할 경우 DiaCell $\mathrm{A}_{1}$ 적혈구는 $84.2 \%$ (Table 3), DiaCell B 적혈구는 $81.2 \%$ 에서(Table 4) 혈구응집 정도가 일치하였다. 본 연구에서 불일치를 보였던 환자와 마찬가지로 응집정도가 불일치하는 경우는 대부분에서 한 단 계 이내였으며, DiaCell $\mathrm{A}_{1}$ 과 DiaCell B 적혈구들 은 두 방법간의 유의한 응집차이는 보이지 않았 다 $(P=0.188)$. 이러한 한 단계까지를 허용범위로 간주하여 두 단계 이상의 차이를 보인 경우를 살 펴보면 $\mathrm{DiaCell} \mathrm{A}_{1}$ 적혈구의 경우 시험관법이 14 건, 겔 원주응집법을 이용한 IH-1000은 12 건에서

Table 4. Number of samples according to the grade of hemagglutination for $\mathrm{ABO}$ serum typing using DiaCell $\mathrm{B}$ between tube and gel column agglutination tests

\begin{tabular}{lcccccc}
\hline \multirow{2}{*}{ Tube } & \multicolumn{5}{c}{ Gel column } & \multicolumn{5}{c}{ agglutination test by $\mathrm{IH}-1000$} \\
\cline { 2 - 7 } & Neg & $1+$ & $2+$ & $3+$ & $4+$ & All \\
\hline Neg & 431 & 0 & 0 & 0 & 0 & 431 \\
$1+$ & 0 & 0 & 0 & 0 & 0 & 0 \\
$2+$ & 0 & 2 & 13 & 4 & 4 & 23 \\
$3+$ & 0 & 4 & 17 & 45 & 91 & 157 \\
$4+$ & 0 & 1 & 16 & 50 & 322 & 389 \\
All & 431 & 7 & 46 & 99 & 417 & 1000 \\
\hline
\end{tabular}


높게 측정되었으나, DiaCell B 적혈구의 경우는 시험관법이 21건, 겔 원주응집법을 이용한 $\mathrm{IH}-1000$ 은 4건에서 높게 측정되어, DiaCell B 적 혈구는 DiaCell $\mathrm{A}_{1}$ 적혈구에 비하여 겔 원주응집 법을 이용한 $\mathrm{IH}-1000$ 보다 시험관법에서 $2+$ 이상 의 더 높게 측정되는 경우가 더 많았다 $(P=0.02)$.

\section{고 찰}

본 연구에서 $\mathrm{ABO}$ 혈청형 검사의 수기 시험관 법에 사용되었던 DiaCell $\mathrm{A}_{1}$ 적혈구 시약과 DiaCell B 적혈구 시약의 기허가 제품과의 일치 도는 각각 $99.9 \%$ 와 $100.0 \%$ 로 식약처 유효성 평가 기준인 $99 \%$ 이상을 모두 만족하였다. 따라서 이 적혈구 시약들은 수기법으로 시행하는 $\mathrm{ABO}$ 혈 액형검사의 혈청형 검사용 혈구로 사용가능한 것 으로 판단하였다.

$\mathrm{DiaCell} \mathrm{A}_{1}$ 적혈구 시약은 대조시약과 비교 시 한 검체에서 불일치를 보였는데, 이 검체는 시험 시약에서는 항-A 동종응집소가 검출되지 않았으 나, 대조시약인 기허가 제품에서는 $1+$ 정도의 약한 항-A 동종응집소가 검출된 경우였다. 이 검 체는 급성골수구백혈병 진단을 받은 77 세 여자 환자의 검체로서 기검사 혈청형 검사에서도 $2+$ 의 약한 응집을 보였고 혈구형 검사에서는 항-B 혈청 시약에 $4+$ 응집을 보여 $\mathrm{B}$ 형으로 판정받았 던 환자였다. 환자의 총단백질과 알부민은 각각 $7.0 \mathrm{~g} / \mathrm{dL}$ 와 $2.4 \mathrm{~g} / \mathrm{dL}$ 로 총 면역글로불린이 $4.6 \mathrm{~g} / \mathrm{dL}$ 으로 정상범위에 있었으나 항 응집소 항체가가 약화된 환자로 추정된다. 비록 혈청형 검사에서 불일치를 보인 검체가 혈청형 검사에서 항응집소 가 검출되지 않아 $\mathrm{AB}$ 형이 의심된다 하더라도, 이 환자의 경우 기검사 결과에서 혈구형 검사상 항-B 혈청 시약에 $4+$ 응집을 보인 것으로 보아 $\mathrm{ABO}$ 혈액형 검사상 혈구형과 혈청형 불일치 때문에
재검이나 다른 요인을 분석하여 $\mathrm{ABO}$ 혈액형 판 정을 실시하였을 것이므로 최종 $\mathrm{ABO}$ 혈액형 판 정에는 문제가 없을 것으로 판단된다.

이러한 항 응집소 역가의 약화는 혈액형 의뢰 검체에서 $\mathrm{ABO}$ 혈구형과 혈청형 불일치의 주요 요인으로 자주 관찰되는 것으로 되어 있다. Immucor microplate 자동화장비에서 $\mathrm{ABO} / \mathrm{Rh}$ 혈 액형 검사를 검토한 보고에서도 자동화 장비의 $\mathrm{ABO}$ 혈구형과 혈청형 불일치 시 주요 사유가 항-A 응집소 혹은 항-B 응집소의 약화 34건, 적혈구 항 원의 약화 5 건, 혼합시야 4 건, $34^{\circ} \mathrm{C}$ 이하에서 고 역가의 한랭항체 8건, 비예기항체 9건과 2건의 아형 $\left(\mathrm{A}_{1}\right.$ 과 $\mathrm{A}_{2}$ 각각 한 건씩)으로 보고하고 있다." 따라서 혈청형 검사에 사용되는 모든 적혈구 시 약은 $\mathrm{ABO}$ 혈액형 판정을 위하여 반드시 혈구형 검사까지 모두 시행한 후에 함께 판정하여야 함 을 강조할 필요가 있겠다.

본 연구에서 DiaCell B 적혈구와 DiaCell $\mathrm{A}_{1}$ 적 혈구는 시험군과 대조군 방법에서 $1+$ 이내의 차 이는 두 방법간에 차이가 없었으나 DiaCell B 적 혈구가 DiaCell $\mathrm{A}_{1}$ 적혈구에 비하여 겔 원주응집 법을 이용한 $\mathrm{IH}-1000$ 보다 시험관법에서 $2+$ 이상 높게 측정되는 경우 더 많아, DiaCell B 적혈구는 시험관법에서 좀 더 민감하게 반응하는 것으로 보여졌다. 시험군과 대조군에 사용되는 적혈구는 동일 제조사의 적혈구로 농도만 달리하였을 뿐이 므로 두 방법간의 혈구응집 차이는 적혈구 제공 자의 B항원 강도의 차이를 완전히 배제할 수는 없으나 적혈구 시약에 따른 차이보다는 시험관법 과 겔 원주응집법간의 차이로 설명할 수 있다. 이 러한 현상은 $\mathrm{ABO}$ 응집소 역가 검사에서 주로 실 온 시험관법이 IH-1000에 사용되는 겔 원주응집 법에 비하여 모든 혈액형에서 항상 높게 측정되 었다는 보고 ${ }^{6}$ 그리고 AutoVue를 이용한 원주응 집법이 수기법보다 혈청형 검사의 혈구응집 강도 
가 더 낮았다는 보고와도기리리챃는 소견이다. 그러나 본 연구에서는 수기 시험관법에서 검출하 지 못하였으나 겔 원주응집법에서만 항-A 응집 소가 검출되어 불일치를 보인 환자의 경우는 DiaCell $\mathrm{A}_{1}$ 을 사용한 경우로 이 경우에는 두 가지 방법 간에 차이를 보이지는 않은 것으로 보여졌 다.

국내 기관의 $85 \%$ 에서 ${ }^{3)} \mathrm{ABO}$ 혈청형 검사 시 수기법 시험관법을 이용하고 있으므로, 본 연구 에서도 임상시험용 체외진단기기인 적혈구 시약 평가 시 수기법으로 시험관법을 이용하였다. 아 직도 국내 의료기관의 $8 \%$ 에서는 여전히 $\mathrm{ABO}$ 혈 청형 검사를 슬라이드법으로 시행하고 있으나, 2013년 미국자료와 2008년 영국 자료에서는 슬라 이드법으로 혈액형 검사를 시행하는 기관은 없는 것으로 보고되기 때문에 수기법으로 시행하는 슬 라이드법 $\mathrm{ABO}$ 혈청형 검사는 시험관법으로 전 환될 필요가 있겠다. ${ }^{8)}$

결론적으로 비록 DiaCell $\mathrm{A}_{1}$ 적혈구 시약이 항-A 응집소가 감소된 1 명의 환자에서 항-A 응집소를 검출하지 못하여 $1+$ 혈구응집을 보여 이를 검출 한 기허가 제품과 차이를 보였기는 하나, 이는 적 혈구 성상의 차이가 아닌 시험관법과 겔 원주응 집법 간의 차이로 보여지며 혈구형 검사까지 반 드시 시행하여야 하는 $\mathrm{ABO}$ 혈액형 검사의 혈청 형 검사 적혈구 시약으로 사용하기에는 무리가 없다고 판단된다. 또한 기허가 제품과의 일치도 가 DiaCell $\mathrm{A}_{1}$ 적혈구 시약과 DiaCell B 적혈구 시 약이 각각 $99.9 \%$ 와 $100.0 \%$ 로 식약처 유효성 평가 기준인 $99 \%$ 이상을 모두 만족하였으므로, 수기 로 시행하는 $\mathrm{ABO}$ 혈액형검사의 혈청형 검사용 혈구로 사용 가능하다고 판단한다. 또한 이 연구 는 향후 체외진단기기 승인을 위한 임상시험의 연구 설계 시 도움을 줄 것이다.

\section{요 약}

배경: 국내에는 식품의약품안전처(이하 식약 처)로부터 허가 받은 수기용 $\mathrm{ABO}$ 혈청형 검사 적혈구 시약은 드문 실정이므로, 수기용 $3 \%$ DiaCell $\mathrm{ABO} \mathrm{A}_{1}$ 적혈구 시약과(DiaCell $\mathrm{A}_{1}$ Biorad, DiaMed, Cressier, Switzerland) DiaCell ABO B 적 혈구 시약을(DiaCell B) 기허가 제품과 비교하여 식약처 수입 허가를 받고자 하였다.

방법: 통상 $\mathrm{ABO}$ 혈액형 혹은 다른 검사 후 잔 여 혈장이나 혈청을 수집하여 시험용 시약인 DiaCell $\mathrm{ABO} \mathrm{A}_{1}$ 및 $\mathrm{B}$ 으로 시험관법을, 대조용 시 약으로는 $\mathrm{DiaCell} \mathrm{ABO} \mathrm{A}_{1}$ 및 $\mathrm{B}$ 과 동일제조사 제 품인 $0.8 \% \mathrm{ID}-\mathrm{DiaCell} \mathrm{ABO} \mathrm{A}_{1}$ 및 $\mathrm{B}$ 적혈구 시약, $\mathrm{NaCl}$ 용 ID-Card, 그리고 IH-1000 자동화장비를 이용하여 혈청형 검사를 시행하였다. 시험용과 대조용 시약간의 일치도, 임상적 민감도와 임상 적 특이도를 산정하였다.

결과: 비교검사는 1000 개 검체에서 시행되었는 데, 일치도는 DiaCell $\mathrm{A}_{1}$ 99.9\%, DiaCell B 100.0\% 였다. 임상적 민감도와 임상적 특이도는 각각 DiaCell $\mathrm{A}_{1}$ 는 $99.9 \%$ 와 $100.0 \%$, DiaCell B은 모두 $100.0 \%$ 였다.

결론: $\mathrm{DiaCell} \mathrm{ABO} \mathrm{A}_{1}$ 및 $\mathrm{B}$ 평가 결과는 식약 처 평가기준인 $99 \%$ 이상을 모두 만족하였으므 로, 수기로 시행하는 $\mathrm{ABO}$ 혈청형 검사 시약으로 사용 가능하다고 판단한다. 또한 이 연구는 향후 체외진단기기 승인을 위한 임상시험의 연구 설계 시 도움을 줄 것이다.

\section{References}

1. Roback JD, Grossman BJ, Harris T, Hillyer CD. Technical manual. 17th ed. Bethesda, Maryland: American Association of Blood Banks, 2011:874-6 
2. Han KS, Park KU, Song EY. Transfusion medicine. 4th ed. Seoul: Korea Medical Book Publisher, 2014:349-52

3. Lim YA, Cho HS, Kwon SW, Kwon KC, Kim SY, Park KU, et al. Annual report on the external quality assessment scheme for blood bank tests in Korea (2015). J Lab Med Qual Assur 2016;38:59-67

4. Ministry of Food and Drug Safety. In vitro medical devices. Guideline on test and performance evaluation for $\mathrm{ABO}$ blood grouping reagents. Cheongju: Ministry of Food and Drug Safety, 2015

5. Xu W, Wan F, Lou Y, Jin J, Mao W. Evaluation of an automated microplate technique in the
Galileo system for $\mathrm{ABO}$ and $\mathrm{Rh}(\mathrm{D})$ blood grouping. Clin Lab 2014;60:241-4

6. Kang SJ, Lim YA, Baik SY. Comparison of ABO antibody titers on the basis of the antibody detection method used. Ann Lab Med 2014;34: 300-6

7. Jo SY, Lee JM, Kim HL, Sin KH, Lee HJ, Chang $\mathrm{CL}$, et al. Comparative analysis of clinical samples showing weak serum reaction on autovue system causing ABO blood typing discrepancies. Ann Lab Med 2017;37:117-23

8. Lim YA. Comprehensive analysis of the testing techniques used in blood bank laboratories in Korea for the past six years. J Lab Med Qual Assur 2014;36:23-9 